\title{
ARTICLES \\ Knowledge, Science, and the Scientist in Contemporary Mythology: A Study of Quasi-Scientific Narratives Collected from People Involved in Russian Religious Organizations
}

\author{
Maria Akhmetova \\ State Republican Center of Russian Folklore \\ Deputy Editor-in-Chief Zhivaia Starina \\ Moscow, Russia
}

When a researcher turns to contemporary mythology she or he probably encounters the problem of whether it is legitimate to describe any contemporary cultural phenomena as mythological. We can talk about this concept only if we first transcend the strict boundaries of the term "mythology." This term means a system of beliefs predating the rational and logic worldview, one that was characteristic of an archaic society. If this system has managed to survive until the present time, it can be found either in non-literary cultures or in the form of fragmented "survivals" in a traditional culture. On the other hand, it is easy to understand myth too broadly, as any text (in a semiotic sense) behind which there is some hidden sense, or using Roland Bart's formulation of myth as "everything that is covered by discourse" [Bart 1996: 233]. In this latter sense the term "mythology" is often used in everyday life and publicity, e.g., in talking about "mass media myths" or "political myths." Here myth is understood as distorted reality, as something deliberate, while references to archaic beliefs, i.e., myth in its primordial meaning, may be missing.

I will use the term "mythology" here as a way of describing and interpreting reality, as a socially meaningful belief that conveys notions about norms and values as well as prescribing certain behaviors [Lezov 1996; Nekliudov 2005]. Mythology often interprets basic philosophical categories like space and time, chaos and cosmos, etc. through concepts that are almost identical for both archaic and contemporary times. Therefore, mythological notions do not disappear in contemporary culture but transform themselves while adapting to new cultural and historical situations. Contemporary mythology in this sense is truly a mythology.

The term contemporary, however, is more problematic. We are forced to keep in mind that the phrase "contemporary mythology" is 
conventional and contains a methodological trap. One can rightly ask: at what stage does a "regular" mythology become "contemporary"? Over the last decade? In the twentieth century? Or, maybe, in the nineteenth century, in the epoch of industrialization, which many researchers consider to be the source of cultural models that are still prevalent in our day? But what is contemporary about the nineteenth century? When we talk about contemporariness itself, in today's Russia for example, villagers still believe in local spirit-masters and in casting the evil eye. Such beliefs are not much different from those recorded several centuries ago. How contemporary is that?

The contradictions disappear at least in part if we agree that contemporary mythology means the contemporary state of mythology or mythology in contemporary culture. Thus we can single out mythological symbols and images in contemporary cultural texts that are familiar from ancient sources. We can trace their transformations and function in our time. Naturally, contemporary mythology does not occupy a separate cultural sphere. On the contrary, mythological views pop up in our mundane speech as well as in literary fiction. Mythology can comprise a considerable part of an ideological concept, whether religious or secular. New myths often appear without any influence from ancient tradition, or at least cannot be linked to it.

There is certainly a difference between how mythology functioned in the past as we have reconstructed it and how it functions today. First of all, myth today does not regulate human life entirely and totally. We may believe in UFOs, but this belief will affect our behavior to a far lesser degree than beliefs in demonological characters would affect a person from a traditional culture. Such a person would explain her or his own misfortunes through the interference of those characters, and she or he would use special amulets for protection from them. But there are spheres where mythological components look most natural and play quite a significant role. An example would be in religion, where many mythological notions have acquired canonical status: any religious system contains components of creation myths, eschatological myths, and the like.

In this article I will look at one aspect of contemporary mythology, namely the adaptation of scientific discourse by Russian religious communities in the twentieth and early twenty-first centuries. It would be a mistake to think of the coalescence of religious and scientific views as immanent to the present day situation only. This phenomenon was characteristic of the industrial era as well. Furthermore, it was present in 
the discourse of different social groups of that time, from the educated upper class, enchanted with Mesmerism and later Theosophy, to the wider urban and rural circles reading popular brochures about the end of the world that portrayed doomsday as a catastrophe caused by a meteor or a collision of the Earth with another planet [Mel'nikova 2004]. The more deeply we look into history the more apparent the syncretism (or undividedness) of scientific, religious, and mythological worldviews becomes. Take the example of medieval alchemy or the scientific philosophy of ancient times. What then is so special about the contemporary situation?

Contemporary society is secular, with a more or less strict division between science and religion. This division is probably most vivid in Russia, with its decades-long history of state-promoted atheism, which stigmatized religion for its "anti-scientific" nature (ironically, only atheism was "scientific" in the USSR). During the Soviet period, statepromoted atheism used the achievements of science as a counterweight to religion. Perhaps the quintessential expression of this was the popular phrase "Gagarin flew into outer space, but he didn't see God." At the end of the twentieth century, the situation of political and cultural crisis created distrust of traditional Soviet values and people turned to religion, or at least to mysticism. This new religiosity often acquired a quasiscientific flavor.(1) At the same time, publications of a religious or mystical nature began to arrive from the West.

The interest of late-Soviet and post-Soviet society in religion, more precisely in Orthodoxy, combined with later, more or less successful government attempts to use Orthodoxy as the foundation for a new national identity. This state of affairs has created the phenomenon of the "Orthodox scientist." The purpose of such a specialist is not only (or, not primarily) to solve scientific problems but to confirm religious ideas. This holds true, even if the scientist positions himself as a representative of academic rather than theological circles. At the same time, some scientists have turned into theologians, explaining religious ideas with the help of scientific terminology, and analyzing scientific problems from the religious point of view.(2) For example, the Head of the AntiDrug Center named for St. John of Kronshtadt, hieromonk Anatolii (Berestov), who is a Doctor of Medicine, considers altered states of consciousness a "delusion or lure," meaning a devilish temptation [Anatolii 2000].

In contemporary culture, the high status of rational knowledge has left its imprint on the worldview of religious communities, many of 
which utilize scientific terminology as a language of communication. For example, regular meetings of the followers of Esotericism are called "lectures" and "seminars." In them, there is repeated reference to scientific discoveries [Ozhiganova 2000: 206]. Both ideologists and followers - and these are mainly city dwellers - of many new religious movements have a postsecondary education. For example, $65.22 \%$ of the followers of Vissarion and $46.4 \%$ of the Moscow community of the Mother of God Center had either begun or completed higher education as of 1998 [Baklanova 1999: 90-91]. And one of the founders of the White Brotherhood (aka the Iusmalians), Iurii Krivonogov (aka Iuoann Svami) has a Ph.D. in Engineering Sciences.

Widening of the informational field does not necessarily lead to rejection of religious doctrine. A.I. Klibanov describes a female Baptist who listened to the radio and read a variety of publications in the 1960s: "all the incoming information is processed. But only bits of it, those relevant to her religious outlook are absorbed; the rest is discarded" [Klibanov 1969: 141]. In the same manner, representatives of contemporary religious groups can read many publications, attend scientific conferences, etc. They then borrow a "foreign" language and adapt it to their own worldview. This happens first of all because the arguments of faith are not sufficient to explain moral norms, so that a spiritual accounting for the universe and rational confirmation is required. For example, "church people" give a "scientific" explanation for lechery by referring to the theory of telegony, holding that offspring can inherit characteristics from the previous mate of the female parent (not the biological father). This idea was popular among neo-Darwinists at the end of the nineteenth century, though it was later discredited. Orthodox believers describe defloration as an act that has far-reaching, even eschatological consequences:

There is a purposefully hidden phenomenon, telegony. I want to say that it is extremely important for young people. Why does God want us to keep faith and purity? This is proven by science $($ sic!) $<\ldots>$ Kinologists, specialists who breed dogs, know that if $\langle\ldots\rangle$ the best dog couples with a non pure-bred bitch $\langle\ldots\rangle$ he has to be dismissed. Because from now on, this pedigreed dog will produce non-pedigreed offspring $<\ldots>$ The same is true with people $<\ldots>$ Look, they preach free love nowadays, "making love" $<\ldots>$ And what if those relationships are just occasional, random, a sort of romantic fling; and what if (the partner) is a scoundrel? And then you marry a nice man, but your child inherits the traits of that scoundrel $<\ldots>$ And if a person has more than one such relationship $<\ldots>$ A girl has sex with one guy, another one, and yet another one; and when all these lines converge it will result in a beast's muzzle $<\ldots>$ A billy-goats' $<$ muzzle $>$. You see, a person, the sort of 
person who engages in (recreational) sex, serves the Antichrist, the devil you know [a female from Murmansk, about 50 years old; recorded in 2002 in the Diveevo Monastery].(3)

Representatives of confessional groups make free use of scientific terminology in their arguments in an attempt to make those arguments sound more "scientific." As a result, religious and mythological concepts acquire scientific confirmation, while scientific notions become mythologized.

The high status of rational knowledge allows representatives of religious groups to juxtapose science and righteousness. The followers of Vissarion speak about their religion as a "school of life." "Correct" education is considered a way to learn about God. An orthodox female pilgrim stated that at a theologian institute one learns not only about "correct history," ancient languages, and how to study God, but also about whom to marry, whether to marry at all, about child-rearing, and so forth. On the other hand, she described learning about God as a process similar to learning to read:

\footnotetext{
Say, $<$ you > visit [a sacred place] that you have studied - then it's like ..., yes, it's just as if you've opened an ABC book. You open the book, but someone has to tell you that this is the letter A, and this is the letter B, and these are syllables. Well, (someone needs to show you) how to put the $<$ letters $>$ together. See what I mean? This is how God reveals himself [a female from Langepas, about 70 years old; recorded in the Diveevo Monastery in 2003].
}

The teaching of Maria Devi Khristos is precisely a "science of the World." The early Iusmalian texts call God's plan to create an earthly heaven an experiment, while Maria Devi Khristos's mission is called the Iusmalos program [Uchenie Marii Devi Khristos 1993]. On the main web page of the White Brotherhood, founded in 2000, its founders declare their intention to reveal God's science to people who would accept their faith. They oppose this kind of science to the obscurantism of the clergy, who brand any such knowledge as witchcraft.(4)

The texts of religious communities reflect beliefs about various fields of knowledge, both those belonging to the hard sciences and to the humanities. Knowledge of the technical sciences and physics is mainly reduced to the idea of "codifying" or "zombifying" radiation that comes from electronics, especially from television sets and computers. Representatives of various movements refer to scientific discoveries and state that electric radiation negatively influences the human subconscious 
and that its effect is detrimental to DNA and so forth. Interestingly, the description of "codifying" radiation often resembles descriptions of the effects of the evil eye or witchcraft that appear in traditional folklore. Just as a person affected by the evil eye or a person possessed has to carry out the will of the witch who bewitched him/her, or the demon inside him/her, so the user of a television or computer is hypnotized through a special code.

Home electronics are often imbued with eschatological meaning. Certain groups associated with the Orthodox Church believe in a gigantic super-computer called "The Beast" through which the Antichrist imposes his will on anyone using a personal computer or getting a personal identification code or a new passport. Technically speaking, the enemies of mankind do this through informational technologies, since the number of the Antichrist, 666, forms the basis of computer calculations. The "mingling" of two terminologies is important in the texts of one Orthodox writer, A. Iakovlev-Kozyrev. He writes about the use of new technologies by the satanic West, which wants to destroy Russia. His writings are replete with phrases like "technogenic-occult invasion," "informational-occult blows," and "electronic antimagic defense" [Elektronnoe zhalo 1999: 32, 35].

In the texts of the Iusmalians and Vissarionians, terminology from physics is used to convey the mechanisms of "fine energies" flooding the universe.

Fokhat is the magnetized energy of God that springs from a single well, a single maternal heart, and spreads throughout the whole universe [a male, about 35 years old, an Iusmalian; recorded in Moscow in 2003].

All the energy constellations now in effect used to have a common conditional positive quality as their Fundamental Principle. And only at a certain stage of the self-development of the active Fundamental Principle into the Integral Whole Essence did an energy environment, which can be conditionally called an environment with a negative quality, start to form.(5)

Biology and genetic engineering in particular acquire special meaning. Authors of Orthodox literature ascribe consciousness and supernatural power, often of a demonic sort, to a cell, to DNA, to viruses and so on.(6) This, for instance, is how the "demonic" essence of a virus is proven: "He $<$ the virus $>$ is a liar; he deceives both the membrane and the ribosome. He is a complete murderer of humans (in the Bible, "murderer of humans" means the devil - M.A.), even more, he is a killer of everything that is alive $\langle\ldots>$ A virus is a frenzied crystal" [Vorob'evskii 2000: 423-424]. 
According to a passage from the Book of Genesis that was adopted by the Christian tradition, God punishes ancestral sins down through several generations. "Church people" understand this idea from an almost medical point of view: sins are transmitted in a manner similar to hereditary diseases; they can even be sexually transmitted:

There is a line of kinship, and if a man sleeps with a woman he takes on her sins, her genealogical traits. She sleeps with a man - she takes on his sins and genealogical traits $\langle\ldots>$ Because the sins of relatives and genealogical traits stick to each other [a female from Langepas, about 70 years old; recorded in the Diveevo Monastery in 2003].(7)

A similar concept of "family sins," which are simultaneously a "genetic code" and are "sealed in the subconscious" [Ioann 1991: Prilozheniie [Appendix]], is found in the early texts of the Head of the Mother of God Center, Archpriest Ioann. The only difference is that, in his texts, the "sinful chalice of a family" is inherited exclusively through the female line and contains mainly the sins of female relatives.

Representatives of religious communities are very much interested in history. This is understandable, since one can comprehend both the present and future by making sense of past events. History is viewed through the prism of conspiracy and all events are seen as a diabolical plot. As M. Khagemeister says, "the conspiracy theory promises to determine the connection between $\langle\ldots\rangle$ a hidden reality and the world in which we live; it gives us an opportunity to 'look behind the scenes,' and explains who 'pulls the ropes"' [Khagemeister 2000: 102]. To break devilish spells, one must consider history anew, overthrow false idols, and rehabilitate the honor of slandered heroes.

This precept goes along with the social aspirations of the end of the twentieth century. The post-Perestroika epoch in Russia was a time when new notions appeared, new values were introduced. A.A. Chernyshov writes of the "Soviet mythology" of the early 1990s, "the most natural spontaneous reaction of society towards a crisis situation is to play with the symbols that represent cultural values. This implies changing established pluses into minuses and vice versa" [Chernyshov 1992]. It is no coincidence that in Russia at the end of the twentieth century, people reflect on the symbols of the new epoch, and simultaneously they reinterpret symbols of the Soviet epoch.

In the field of history, the most active process is the process of reinterpretation, "the changing of signs." The need to reinterpret history is explained by the belief that enemies deliberately distorted it.(8) I heard from the Orthodox faithful about "fake" history that was produced by the 
Masons. As a male Iusmalian follower explained, "the Jews" appropriated the merits of the Slavs and thus "have left them without their culture," since "the Zionist Protocol prescribes giving false ideas about history" [a male, about 35 years old; recorded in Moscow in 2003].

In church circles the images of historical characters are being reinterpreted. This process began with the "rehabilitation" of Tsar Nicholas II and, starting in the second half of the 1990s, spread to other historical characters who were once considered odious. Thus Ivan the Terrible is now seen as a good ruler who fought against the Jews; Gregory Rasputin has become a perspicacious man, a friend of the tsar's family; Paul I has been reconsidered, and so forth. The mendacious Masons are accused of having defamed and slandered all Russian sovereigns. And the historical truth can be found only in "Orthodox," not "Masonic," books:

\begin{abstract}
And in reality, according to the Orthodox book it goes like this: Ivan the Terrible would not eat a bowl of porridge without bowing to the ground in prayer a thousand times. Only then would he eat. His son was a believer as well; he died on a pilgrimage. He was sick. And here they went and ordered a canvas (entitled) "Ivan the Terrible kills his son." He did not kill him. Why was he "Terrible"? $<\mathrm{He}>$ conquered the city of Kazan'. And $<\ldots>$ Catherine II - how is she $<$ presented $>$ : as a so-and-so, a debauched woman $<\ldots>$. And in reality - even though she was a sovereign of German origin - she brought a renaissance; she ruled for 34 years [a male from Vladivostok, 45 years old; recorded in the Diveevo Monastery in 2003].
\end{abstract}

At the same time, other historical characters, from both secular and sacred history, have changed their polarity from "plus" to "minus." This is true not only with respect to Lenin and the revolutionaries. At the Mother of God Center, for example, the personage of the Reverend Josef Volotskii was reinterpreted and he became the "father of the Russian Inquisition." The Iusmalians have a negative view of the Apostle Paul the Persecutor because they feel that God revealed His identity to him only to defend the Christians, "so that he would not annihilate the remaining ones." Paul, they argue, did not know Christ personally and replaced the image of the gracious Savior with the formidable Yahweh from the Old Testament in his epistles [an Iusmalian female, about 35 years old; recorded in Moscow in 2003].

The attitude towards Peter I is ambiguous: some circles close to the church view him most positively. The Mother of God Center views him negatively and the White Brotherhood is indifferent ("he cared about the empire, but he was not ecclesiastical"). As might be expected, the 
representatives of the Orthodox Brotherhood named for Tsar-Expiator Nicholas II closely affiliated with the almanac Zhizn' Vechnaia [The Eternal Life] reiterate the views of its chief editor, V.P. Kuznetsov. He treats the image of the tsar-reformer positively. This group emphasizes that Kuznetsov has restored the truth about the slandered monarch, and thus discredited the conventional stereotype:

As for Peter I - he (Kuznetsov) studied him for about twenty years and totally discredited the image of Peter as a destroyer of the church. In fact, the opposite is true. All the Saints honored Peter as a sacred tsar, even more - as the most pious tsar $<\ldots>$ [The collector: "Did he have a special education?"]. Well, he was his own education. Because in the seminary - they don't specifically; there is a program there $<\ldots>$ (Just think) who the professors are. [a male from Moscow, about 50 years old; recorded in the Diveevo Monastery in 2003].

Attitudes towards Hitler and Stalin are equivocal as well. In the context of the condemnation of totalitarianism, these historical figures are viewed as precursors of the Antichrist. But in the context of antiSemitism they are treated with some empathy, though cautiously:

\begin{abstract}
Stalin is a different matter. All the Masons ... he fought the Jews. [He was of the Christian faith. - Interlocutor's remark]. He was a Christian. First, he was Georgian, and second - it is interesting that he was... well, of course he was the worst of all criminals, that is he ruled brutally, but as for the Jews... There is a lot of blood on his hands, but he fought the Masonry. I do not want to really revile him. There is a powerful campaign against him right now... [an Orthodox female from Murmansk; recorded in the Diveevo Monastery in 2002].

Hitler did not realize that violence was not the way to purify the Aryan race. He was not a spiritual man. He did a very stupid thing, but he meant to do better [an Iusmalian male, about 35 years old; recorded in Moscow in 2003].
\end{abstract}

The followers of Vissarion reevaluate the very concept of teaching history. In order for the young generation not to "fall for the bait of the kingdom of power, which happens through history textbooks" [Zemlia obetovannaia [The Promised Land], 1996, Nos. 11-12: 22-23], the teacher must leave aside accounts of wars and other manifestations of violence and pay more attention to what the arts were like during the historical time period being studied. Philology attracts attention as well. The search for the etymology of concepts with either pronounced positive or strongly negative connotations that are related to either an actual historical period (i.e., the Soviet era) or the contemporary situation helps to reveal the true meaning of events. 
Circles closely affiliated with the church produce "translations," a kind of folk etymology of words such as democracy (the power of the demons), a democrat (a demon divisible), and demonstration (a procession of demons from "demon," a Greek word for "devil," and "stratio" the Latin word for a procession). Similarly, revolution becomes a Zionist coup (from revolu-tion [in Russian, there can be confusion between the initial letter of the syllable -tion and the sound of the first letter in the Russian word for Zion - Sion Trans.]) and so on. Some interesting etymologies are based on abbreviations. For example, the phrase "passport SSSR" [a USSR passport] is deciphered as "pechat" antikhrista sam poluchaiu, sam soediniaius' $s$ satanoi" [I receive the stamp of the Antichrist, uniting myself with Satan]. The Catacomb Church of the Eastern Heavenly Apocalyptic Church of the Revelation of St. John the Theologian (Ioann Bogoslov), in its periodical publications, treats the word ваучер [voucher] as an abbreviation that stands for "vozvrat adskogo ugneteniia chelovechestva, egipetskogo rabstva" [return of the hellish oppression of humankind, of Egyptian slavery] [Nebesnyi Grad [The Heavenly City], 1993, No. 6, p. 4]. Other artificial etymologies are also created. For example, members of the White Brotherhood derive the word proletarii [proletarian] from the imagined word letarii, which they connect to spiritual death. Letarii is a soulless "astral mutant," whose consciousness does not develop, and these are the kind of creatures that Lenin gathered to create the USSR [cited from http://www.usmalos.com/teoeons/html.htm].

Words and symbols of the contemporary epoch also acquire new etymological explanations. The church-related circles translate the word president "from Latin" as "initiated' (meaning into Masonry) or "from church language" (sic!) as an "impostor, a political thief." By pronouncing these words, a person unconsciously renounces God and denigrates his or her own Russian and Orthodox dignity:

\footnotetext{
"These are all word-fetters; they (the Masons - M.A.) imposed them on us secretly so that a person would pronounce them. And when a person does pronounce them, he commits blasphemy" [an Orthodox male, about 35 year old; recorded in the Diveevo Monastery in 2003].
}

Words with negative connotations are viewed as purposefully ciphered by our enemies for the profanation of the Russian people. This is similar to the notion that "mat" (a Russian obscene language based on the root of the word for "mother") is a "Jewish" or "Tatar" language and thus devilish in origin. 
The search for the etymology of toponyms, the names of cities and rivers, serves a different purpose. First of all, such etymology proves the Slavic origin of those names and thus serves to glorify a chosen people. This practice is especially characteristic of neopagan groups. The Iusmalians find Russian roots primarily in Holy Land sites:

\begin{abstract}
This city, Ierihon is really Iarkhon, a purely Russian city. And the Jordan River is Iardon: "don" is a river in Russian, and "iar" - well, it is a bright river. The Fire river $\langle\ldots\rangle$ of Estrus - the language here is clearly Russian; here are the words. If you read them (carefully) you will understand everything $\langle\ldots\rangle$ But the whole world says this is an old, ancient language impossible to decipher. They would say anything to denigrate the Russian man $\langle\ldots\rangle$ The Russian man gave culture to everyone. And always gave it. But recent times are like godless times, a time when all values are defiled. He (the Russian man) is denigrated, even in a Biblical way. Everything the Russians have done is ascribed to the Jews [an Iusmalian male, about 35 years old; recorded in Moscow in 2003].
\end{abstract}

Simultaneously, the names of Russian locations are interpreted via other languages in order to prove their sacredness and special mission. For example, activists of the Orthodox Brotherhood named after TsarExpiator Nicholas II foretold that the last righteous tsar would be revealed in Sarov. According to their reasoning, the root "sar" of the word Sarov is genetically related to the word "tsar" in many ancient languages.

Finally, there is the notion of a special spiritual language. Thus, Maria Devi Khristos speaks about samskryt, the "most ancient Language in the World, which the proto-Slavs, the ancient Rus'ians, the children of Beautiful Hyperborea, spoke"

[cited from http://www.usmalos.com/teo/slovar.shtml]. No doubt the idea for this language arose under the influence of the neopagan concepts. The primordial language samskryt (from Russian сам скрыл 'selfhidden') is said to convey only notions imbued with sacred meaning. At the same time there supposedly exists a satanic language, which will supplant both divine and human languages in the time of the Antichrist. This language is numerical:

The names of streets, regions, and countries will have their numerical sign, a string of numbers. There will be a unified international language of Satan, a numerical one. For example, "a human" is number 6; "to drink" is number 1; "to eat" is number 2 and so on. In the course of several months humans will unlearn how to speak, love, and feel, and will turn into the dead slaves of Satan, into zombies [Uchenie Marii Devi Khristos 1993: 8]. 
Therefore, the language of the written mysteries of the World has a dual origin. On the one hand, the creator of this language is the devil himself, along with his closest allies, the Jews. On the other hand, it might originate in the upper world and be connected to the language of the God-bearing Russian people. It is noteworthy that the interpretation of words that have positive connotations is revealed through the Russian language, while the number of Russian roots in words that have negative connotations is minimal.(9)

People who interpret words in this way are not concerned with the language from which some notion is drawn. In this respect, it is significant how the word computer, a symbolical word in the mythology of church circles, is etymologized:

When I was praying - that was in 1997 - "The Lord, let me know what the apocalyptical beast is" $<\ldots>$ And God revealed that it was a computer. And then I began searching and found out that "compu" stands for computation in English. And "ter" stands for a "devouring beast" in Ancient Greek. Therefore, you have "computation of a beast." [Some] derive this word in another way. "Com" stands for commissar, communist, comsomol member, computer, i.e., they all have the root "com," which ... they all are a false prophecy. That is, they all are false prophets. Then "pu" stands for a "dragon" in Japanese $\langle\ldots>$ [They] draw little pictures, little dragons, and there is a word "pu" beneath. And "ter" stands for a "devouring beast" in Ancient Greek. And here you have the apocalyptic (triad), here, there is written in the Apocalypse: three unclean spirits will come out from the mouth of a false prophet, a dragon, and a beast. And according to the revelation - I have not found this yet - but according to the revelation "com," "pu," and "ter" are numbers in ancient languages, numbers $6<\ldots>$ (interlocutor: "What would "com" be?) "Com" - well, I do not know myself; it is probably a spirit, the spirit itself. Of the Antichrist, "com" [an Orthodox male, about 35 years old; recorded in Diveevo Monastery in 2003].

The narrative above demonstrates nicely how the logic of eschatological interpretation works. Those who apply this interpretation imagine the Apocalypse as a book where the mysteries of both future and present are encoded. They think that these mysteries can be grasped by humans, but only through God's revelation. Words are translated from real or hypothetical "ancient languages," and different parts of a word can be translated from different languages. Lack of linguistic logic does not bother the interpreters since, for them, the essence of the message is more important than logic. Despite their quasi-scientific nature, these interpretations bear a strong resemblance to folk etymology: 
Do you know how to translate "revolution"? It is from English, but just translated into Russian: "revolu-tion." And in Latin it is "revolu-tion." Did you know? "Revol" means "revolt." The word "revolver" means "barrel," yes. And "tion" means "Zion." The Zionist revolt. "Revolution." (Interlocutor: "In Latin"?) No. One word is in Latin and the other in the Aramaic language. Because, for example, a letter " $\mathrm{t}$ " is absent in Aramaic. And the letter "s" is present [an Orthodox male from Moscow, about 35 years old; recorded in the Diveevo Monastery in 2002].

This interpretative narrative is structured as if to imitate an entry in an etymological dictionary, only presented orally. It contains references to various translations, graphic images of the interpreted word, and a discussion of the relationship of its parts to various words. Behind these claims to scientific rigor, however, is the principle of folk etymology: a formal exercise singling out the significant element in the interpreted word (in this case, Zion) [Gridina 1989: 24].

Finally, contemporary Iusmalians revise the laws of astronomy. The idea that the Earth revolves around the Sun, while the Moon revolves around the Earth, is seen as the greatest lie created to denigrate the divine principle of the unity of the male essence (the Sun) and the female essence (the Moon), as manifested on the Earth:

Then, since the time of Copernicus, the dark forces have been making huge inroads $\langle\ldots\rangle$ They have destroyed it; [they] said that the Earth is, well, God knows where, on the edge of the galaxy. Our system and the Earth are revolving around the Sun. [Copernicus] belittled, denigrated this most sacred planet in the universe that is in the center of this universe ... where all the mature souls from around the universe come to get spiritual experience $<\ldots>$ It is really - the very nucleus of the Sun - if we do not count the halo of luminescence, which is very powerful, it is the same as the Moon's disk. In terms of size. And the Earth is two times larger than either of them. In relation to them, she is both mother and daughter. They guard her like a father and mother. [They guard] the Earth. And [they] feed [the Earth]. The Moon feeds the waters, and the Sun - fire. But the Earth is chronologically older. She appeared first in the material world. The Sun and the Moon appeared after her. And then [appeared] the rest of the comets and planets [an Iusmalian male, about 35 years old; recorded in Moscow in 2003].

The White Brotherhood probably derive their reformulation of astronomy not from archaic cosmology, when the Earth was indeed thought to appear before the Sun and Moon. Rather, the motivation for their views is the idea that standard astronomy is a conspiracy against the truth.

Interestingly, representatives of religious communities manifest their rejection of rational knowledge by extensive use of scientific 
discourse. They equate secular educations with godless upbringing. A person serves the demons by studying at a secular university:

The fact that you were admitted [to the Historical Department], [to study] secular history - this is from the devil. You serve Satan. [You serve] the unclean forces, do you understand? [You serve] the Masons. They create a history of their own, that is mendacious history [an Orthodox female from Langepas, about 70 years old; recorded in the Diveevo Monastery in 2003].

A complete taboo on rational knowledge is characteristic of the writings of the Mother of God Center. Archpriest Ioann speaks about rationalism, along with lechery and deceit, as manifestations of the satanic spirit. People infected with this spirit will, according to him, contract diseases of the brain [Bogorodichnoe lono 1992: 76]. The more humankind develops rational knowledge and secular culture, the further it distances itself from the truth:

The appearance of writing [caused] a loss of the capacity for oral ingenious communication with God $\langle\ldots\rangle$ The appearance of book-printing [caused] a total degeneration of the Word, its "interception" by servants of the Prince of Darkness [Ioann 1994: 13].

One early writing of the White Brotherhood includes a poem by Iuoann Svami with a characteristic title "The Scientific Atheists-Demons." In the endnotes, the author expresses his regret that he had written a scholarly dissertation instead of devoting that time to "spiritual questions" [Poema 1993: 3].

Sometimes science is even juxtaposed with witchcraft. It is perceived as the work of the enemy, who want to bring the Antichrist into power. Beliefs about medicine, especially psychology and biology, best illustrate this. Orthodox literature and narratives of the "church people" frequently assert that biology in the form of cloning, artificial insemination, organ transplants and so on is used by our enemies to breed a new type of person who will carry out the will of the Antichrist. In addition, by propagating mixed marriages and sexual licentiousness, the enemies obliterate nationality in order to rob a man of his roots, i.e. the information contained in his genes. Such people would gladly accept the Antichrist. Medical advances are often compared to witchcraft: Orthodox writer IU. Vorob'evskii calls fetal therapy the "the witch use of embryos" [Vorob'evskii 2000: 174]. The advances of medicine are said to cause intentional harm. As the aforementioned author states, enemies cause genetic mutations in people, especially Slavic people, by importing 
foods with added "agents that are harmful for a certain ethnicity" [Vorob'evskii 2000: 88]. Deadly injections are given instead of shots in order to rid the world of Russians:

The hepatitis B and C viruses, along with the AIDS virus, were generated by genetic engineering as a bacteriological weapon. This is the opinion of many world scientists $\langle\ldots\rangle$ And the creators of those infections will have to wait a long time before we contract the infections and die out. And in order to facilitate this process [they] vaccinate all our infants, children, teenagers, and adults - the latter still voluntarily - (giving them) the plausible excuse of thus protecting them against hepatitis $\mathrm{B}$ and $\mathrm{C}$, but (in reality) dooming them to death. And the posthumous diagnoses will vary. And we will bury each other and thus free our lands for "the fortunate of the golden billion," for whom we are just sub-humans, or goys!(10)

The shots [vaccinations] are also interpreted as a brand of the Antichrist:

And [they] will be making cuts on arms and veins on the pretext of giving shots. There will be three consecutive cuts. And each will be called "I, the son of the Antichrist," since it will be incest. [They] will infuse the Antichrist's blood into the blood of Orthodox Christians [Dukhovnoe 2003].

The Antichrist himself is viewed as a product of biological experiments. For example, it is said that an artificial human "from a test-tube" will turn into the Antichrist. According to a less popular view, Lenin, revived by geneticists, will become the Antichrist. Genetic engineering itself is thought to exist only to "revive some 'great historical character,' who will possess unrestricted power over the living on Earth due to the accepted supernatural force of universal worship after death" [Oprichnyi listok, No. 16].

Psychology conceals a demonic potential as well. Circles near the church perceive hypnosis, coding (a method of treating alcoholism and smoking dependency), and hypnotic suggestion as intrusions into the human soul with the help of demonic forces that will ultimately lead to a state of possession. "Church people" often reduce the whole science of psychology to the technique of hypnotic suggestion. An Orthodox pilgrim said about her acquaintance, a professional psychologist:

I read her books, this psychology, [and] said: "Enough, I understand nothing here, but even with all your knowledge - you won't get me. I will pray (the influence) away. [Interlocutor: "Does it mean that a psychologist can harm you?"] Of course. They become [psychologists] and start treating people with hypnosis. This is the way they write - through hypnosis. Where do they get it from? This is the same thing, this biofield, human energy [a female from 
Khabarovsk, about 55 years old; recorded in the Diveevo Monastery in 2002].

Quite often demonic functions are ascribed to scientists. For example, this is how Orthodox writer IU. Vorob'evskii comments on research into super high frequencies at the Institute of Biophysics and their impact on humans. Claiming that the experiments cause humans to hear voices, he writes:

Therefore, science is mimicking what infernal agents do. What we are talking about is nothing other than creating a state of possession through technetronic means. Scientists who have lost their spiritual axis are voluntarily taking over the job of demons. And the latter can just rub their paws and laugh. [Vorob'evskii 2000: 41].

Traditional culture, and quite often mass consciousness as well, is typically wary of conventional medicine, which is perceived as something alien and related to harmful or unclean forces. A negative attitude towards genetics, which was presumably inspired by the Antichrist, and towards cybernetics [see Oprichnyi listok, No. 28; Vorob'evskii 2000], has certain historical foundations. This attitude is linked to a negative view of foreigners and Jews and is reflected in a number of texts in Russian culture. These range from parodic recipes from the seventeenth century, when foreign pharmacists were portrayed as prescribing medication that "cured" one of life [Russkaia satira, 1977: $218](11)$ to the ideologies of the 1930-50s that claimed harm was perpetrated on the pretext of curing by "doctor-saboteurs" and "killers in white robes." Urban legends like those from the 1980s continue this trend and tell of vengeful doctors who "turned" a child into a dog through surgery [Novichkova 2001: 221].(12) This image of the doctorsaboteur is frequent in contemporary mass culture where a number of popular pseudo-detective and "yellow journalism" publications portray criminal doctors who trade in human organs and aborted fetuses and who turn healthy people into cripples.

The negative mythology about science and scientists in the concepts of the White Brotherhood, both the current and the earlier one, closely parallels scientific advances. As one Iusmalian [a male, about 35 years old; recorded in Moscow in 2002] states, humans are created from a testtube because such humans are easy to control, while experiments in the area of cloning are directed toward the eschatological future: 
They are making lopsided advances in this science so that it would develop this way. Look, they've started cloning. Because experiments on other planets have proven that a human with implanted microchips loses the ability to procreate. Yes, the emotional sphere is inhibited to such an extent that a human cannot procreate while under computer supervision. Hence, the need to clone. And they start cloning not when a human loses the ability to procreate, but now that there is no such threat. In this way he will be in full armor, so to speak, by the time (that he is needed).

In its writings, the Mother of God Center ascribes eschatological meaning to clones and "test-tube babies." In one of the revelations, an angel tells Ioann (Bereslavskii) about the "madmen who will come into the world with the idea of improving the human race," a presumed reference to geneticists:

Then those servants of the Satan will invent preposterous experiments on brains, hearts, and bodies, as well as various awful interbreeding programs and organ transplants from one human to another. The whole earth will turn into the most loathsome laboratory of the devil [Otkroveniia, 1991: 23].

And Ioann warns on his own behalf:

Do you reject the prophecy of the kingdom of the saints? Then you will involuntarily summon and bless the devil-civilization of the test-tube homunculus. Upon maturation, they will turn into beasts of prey and devour everyone around them, including you $\langle\ldots\rangle$ These children [born from artificial insemination] are an awful apocalyptic harbinger of the last of days. The more of them that appear the closer approaches what humankind fears the most, but what will inevitably come <.. > [Ioann 2000: 8].

Peasants in old Russia ascribed a satanic and even eschatological meaning to medicine. For example, at the beginning of the nineteenth century the dwellers of several provinces refused to be vaccinated against smallpox because they thought it was the brand of the Antichrist [Rovinskii 2002: 263]. Contemporary believers in the apocalypse speak about doctor-Masons who kill Slavic women and their newborn babies in hospitals [a female from Belarus', about 25 years old; recorded in the Diveevo Monastery in 2002]. Religious publications of various communities contain reports about the deliberate poisoning of the Slavs by medications prepared by the Jews [Gordeev]. They tell about doctorvampires who appear before the end of the world to suck donors' blood [Poema, 1993: 54, 81] etc. These images, however, are now in line, not with folk culture, but with contemporary urban culture. Part of the sinister image of doctors and, more broadly scientists, as allies of the 
Antichrist, comes from Soviet punitive psychiatry, from doctors experimenting on prisoners in Nazi concentration camps, and from scientists discovering the atomic bomb, which really could destroy the world. Thus scientists running experiments appear potentially destructive of the cosmos. The latter idea is very popular among contemporary villagers, whose worldview is influenced by urban culture to a large degree. Here is an indicative excerpt from a dialogue:

1: These birds - why they are able to fly so far: that's what scientists have taught them $<\ldots>$

2: They did say that those scientists would ruin the world [Cited by Maslinskii 2000: 99].

Suspicion directed at science results in an ambivalent attitude towards education and knowledge per se. For example, the contemporary Orthodox writer G. Emel'ianenko, Doctor of Philosophy has written the article "The Genetic Corruption of the Russian Eve by Foreign Languages." In it he argues that females should not learn foreign languages because these languages will change their thinking and make them adopt the values of other cultures. He cites the advances of psycholinguistics, which "have proven that any newly acquired-learned language totally controls the brain, the thinking, and the will of the person who has learned it":

Those foreign languages that a female student would learn in the godless circumstances of a university education plague her, poor creature, throughout her life $<\ldots>$ In a young contemporary neopagan girl $<\ldots>$ a foreign language immediately bonds $\langle\ldots>$ to original sin (i.e., a false word), and a nuclear reaction of body-flesh corruption begins. In our country, for example, it is common knowledge, both public and private, that the prestigious universities of foreign languages used to be the main suppliers of the most expensive foreign-currency prostitutes. Nowadays they produce just universal international ladies, who are absolutely attuned to Western hell $<\ldots>$ Scientists themselves have discovered that female thinking is governed solely by the right hemisphere $\langle\ldots\rangle$ and any institute of foreign languages is a purely numerical, discrete system requiring use of the left hemisphere... Therefore, female anthropology and brain structure are not suitable for studying or perceiving a foreign language. Neopagan pop-mechanics completely ruins both (a woman's) psyche and her morality. And yet she must care for menfolk and for children... [Emel'ianenko 2000: 311-312].

Representatives of religious communities accept information even from completely secular sources if that information supports their worldviews. Here is an example of Iusmalian reasoning: 
There is the academician, Bestuzhev-Lada from the Academy of Sciences. He says $\langle\ldots\rangle$ that the crossbreeding of a human with a computer is planned for around the 2030s. This is a State program. It is not some religious or mystical field; this is the field of futurology. It is a science of societal dynamics, yes. And he is not at all a religious man, this Bestuzhev-Lada. He couldn't care less about all these religions, all the confessions; he just gives talks and says to people that there is now, well, he does not call it a threat, because he is not a religious man, so he can't know whether that is a threat or not [a male, about 35 years old; recorded in Moscow in 2003].

There is even direct borrowing, or plagiarism, from scientific texts by confessional circles. Below is a comparison of excerpts from two texts. On the right is a well-known article by Boris A. Uspenskii about obscene language. On the left is an article from the ecumenical newspaper Delo Very [The Work of Faith] published in the city of Izhevsk. Its author was certainly familiar with Uspenskii's article, as the highlighted quotes prove. After presenting some of Uspenskii's ideas, however, the Christian author changes the conclusions. Uspenskii presents his conclusions about obscenities directed against the parents of a person who uses them as a hypothesis, while the Christian author presents them as absolute truth.

\begin{tabular}{|c|c|}
\hline $\begin{array}{l}\text { "Mat v tri khoda" [A Three Move } \\
\text { Checkmate](13) Delo very, 2004, No. } \\
\text { 2(82), March - April }\end{array}$ & $\begin{array}{l}\text { B.A. Uspenskii, "A Mythological Aspect of } \\
\text { Russian Expressive Phraseology" The Anti- } \\
\text { World of Russian Culture. Moscow, 1996, } \\
\text { pp. 9-107 }\end{array}$ \\
\hline $\begin{array}{l}\text { Obscenity has a distinctive worshiping } \\
\text { function in Slavic paganism. It is widely } \\
\text { presented in rituals of a pagan origin, } \\
\text { and it bears a ritual character. }\end{array}$ & $\begin{array}{l}\text { Indeed, obscene language is widely } \\
\text { presented in various rituals of clearly pagan } \\
\text { origin like weddings, agricultural rituals and } \\
\text { the like, i.e. in rituals, which in one or the } \\
\text { other way are connected to fertility. Obscene } \\
\text { language is a necessary component of such } \\
\text { rituals and it undoubtedly bears a ritual } \\
\text { character }<\ldots>\end{array}$ \\
\hline $\begin{array}{l}\text { At the same time obscenity has a } \\
\text { distinctively expressed anti-Christian } \\
\text { character. In the ancient Russian } \\
\text { manuscripts, harsh language is viewed } \\
\text { as a trait of demonic behavior. }\end{array}$ & $\begin{array}{l}\text { At the same time obscene language has a } \\
\text { distinctively expressed anti-Christian } \\
\text { character that is related to its pagan origin. } \\
\text { Accordingly, in the ancient Russian } \\
\text { hieroglyphics - in circumstances of } \\
\text { Christian-pagan dual belief - obscenity is } \\
\text { viewed as a trait of demonic behavior (p. } \\
\text { 14). }\end{array}$ \\
\hline $\begin{array}{l}\text { Among the Slavs, obscenity performs } \\
\text { the function of a curse. For example, }\end{array}$ & $\begin{array}{l}\text { In this respect, I should note that among the } \\
\text { Slavs obscenity can perform the function of }\end{array}$ \\
\hline
\end{tabular}

FOLKLORICA 2008, Vol. XIII 


\begin{tabular}{|l|l|}
\hline $\begin{array}{l}\text { one obscene word that starts with the } \\
\text { letter "e" and has a Slavic origin, can be } \\
\text { translated as "to curse." }\end{array}$ & $\begin{array}{l}\text { a curse }<\ldots>\text { Accordingly, a verb derived } \\
\text { from the Slavic *jebati, can acquire the } \\
\text { meaning 'to curse' ... (pp. 20, 21) }\end{array}$ \\
\hline $\begin{array}{l}\text { By pronouncing it [an obscene word] a } \\
\text { human curses himself and those around } \\
\text { him }<\ldots>\text { The one who pronounces such } \\
\begin{array}{l}\text { words automatically summons demons } \\
\text { upon himself, his children, and his kin. }\end{array}\end{array}$ & $\begin{array}{l}<\ldots>\text { thus obscenity, by insulting the parents } \\
\text { of a person who pronounces it, insults him as } \\
\text { a representative and successor of his kin... } \\
\text { (p. 35) }\end{array}$ \\
\hline
\end{tabular}

Thus, it is not enough for representatives of contemporary religious communities to explain the moral norms and the spiritual cornerstones of the universe solely through arguments of faith. Instead, they strive for rational, scientific confirmation. While borrowing scientific discourse, however, they adapt it to their mythical worldview.

Do representatives of such communities themselves differentiate 'scientific' and 'mythological' ideas? I think that such a differentiation exists only in the minds of researchers; it is not foremost in the minds of the confessional congregations. When representatives of religious communities describe the world using a quasi-scientific language and reveal the secrets of the universe with the help of "scientific" methods, the standard mode of the secular discourse, they do so to demonstrate that, for them, science belongs to God's Providence, just like other spheres of life. Differentiation between science and religion occurs only when it is necessary to juxtapose God's truth and the sinful contemporary world. That is when the negative image of science and the scientist appears. Here we notice the influence of traditional culture where 'to know' means, among other things, 'to possess a magical gift,' which makes a scientist or a doctor akin to a wizard.

\section{NOTES}

1 The fate of the journal Science and Religion is significant in this respect. It was founded in 1959 as a mouthpiece for the ideas of scientific atheism. During Perestroika, it started publishing quite amicable articles about traditional religions as well as about yoga, chiromancy, astrology, unconventional healing, parapsychology, the mystical implications of World history, and the like. Nowadays, there is almost nothing "scientific" left in that journal.

2 Borrowing of contextual elements from scientific discourse is typical for theological discourse as well. In such cases these elements acquire new qualities [Lezov 1996: 16]. 
3 This considerably reduced narrative is a free retelling of the leaflet "Telegonic science about virginity" whose author is Nikolai Goloikin, an archpriest. This leaflet became widely known due to numerous reprintings by several publishing houses and through online distribution.

4 Citing from http://www.usmalos.com/ (Consulted 2003)

5 Vissarion. Время поворота [The Time of the Turn]. Cited by: http://www.vissarion.ru/rus/turntime/turntime01_r_w.html. (Consulted 2003)

6 Compare this to the esoteric healing practice of talking to every organ, every cell, which are presumably alive and understand the commands to get well.

7 Compare this to the taboo on blood transfusion, derived from the idea that something of the human soul is contained in the blood.

8 Compare this to A.T. Fomenko's idea of a "conspiracy against history." According to Fomenko, Russian history was distorted by the Romanov dynasty in order to conceal the origin of the previous dynasty (see Fomenko 1993: 183-84).

9 Circles near the church view the Russian, and especially the Church-Slavonic, language as sacred. It is not surprising that their representatives perceive the grammar reform as another denigration of the Russian people. Note the popular interpretation of the replacement of a letter " $z$ " by "s" in prefix "bes" as summoning the demons [Tarabukina $2000]$.

10 "Herods of the 21st century: on the hepatitis shots" Pervyi i poslednii, 2003, No. 3(7). Cited by:

http://www.zaistinu.ru/skrest/sk/88_irods21.shtml. (Consulted 2003)

Translator's remark: goi is a derogatory word for non-Jews in the Yiddish language. Thus, the author's anti-Semitic stance is evident.

11 See discussion of the image of doctor-quacks and saboteurs in the texts of European Medieval folk culture in Reutin 1996: 197-98.

12 See the discussion of Russian anti-doctor discourse in the 18th19th centuries in Bogdanov 2005.

13 Here the title "Mat v tri khoda" is wordplay, since the Russian word mat stands for both an obscene language and a situation in chess. 


\section{BIBLIOGRAPHY}

Anatolii [Hyromonk Anatolii (Berestov)]. 2000. Анатолий (Иеромонах Анатолий (Берестов)). Число Зверя на пороге третьего тысячелетия [The Beast Number on the Threshold of the Third Millennium]. Москва.

Baklanova, G.IU. 1999. Бакланова, Г.Ю. Православная ичерковь Божьей Матери “Державная" (сочиально-философский очерк) [Orthodox Church of the Mother of God "Derzhavnaia" (a SocioPhilosophical Essay)]. Москва.

Bart, R. 1996. Барт, Р. Мифологии [Mythologies]. Москва.

Bogdanov, K.А. 2005. Богданов, К.А. Врачи, пациенты, читатели:

Патографические тексты русской культуры XVIII-XIX вв. [Doctors, patients, readers: The Pathographical Texts of the Russian Culture of the $18^{\text {th }}-19^{\text {th }}$ Centuries]. Москва.

Chernyshov, A. 1992. Чернышов, А. Современная советская мифология [Contemporary Soviet Mythology]. Тверь. Cited by http://www.ruthenia.ru/folklore/chernyshov1.htm. consulted 7 July, 2008.

Emel'ianenko, G. 2000. Емельяненко, Г. “Генетическое развращение русской Евы иностранными языками" [The Genetic Corruption of the Russian Eve by Foreign Languages], О Женщина! Велика вера твоя. Санкт-Петербург. 310-314.

Fomenko, T.А 1993. Фоменко, Т.А. Критика традиционной хронологии античности и средневековья (какой сейчас век?) [A Critique on Traditional Chronology of Antiquity and Middle Ages (which century is it now?)]. Реферат. Москва.

Gordeev, K. 2003. Гордеев, К. Цель революччи в России [The Aim of Revolution in Russia]. An online resource: http://www.kongord.ru/ Index/Ch_vs_ss/Zion/IoannPlamenny/REVOLUTION.htm. consulted 2003.

Gridina, Т.А. 1989. Гридина, Т.А. Проблемь изучения народной этимологии: Пособие к спеикурсу [Problems in the Study of Folk Etymology: Textbook for an Elective Course]. Свердловск.

Ioann [Archbishop Ioann (Bereslavskii)]. 1994. Иоанн (Архиепископ Иоанн (Береславский)). Огонь покаянньй. Путь святых отцов [A Penitential Fire. The Way of the Holy Fathers]. Книга 4, Москва. 
Ioann [Archbishop Ioann (Bereslavskii)]. 2000. Иоанн (Архиепископ Иоанн (Береславский)). Время всероссийского покаяния [Тhe Time of All-Russian Atonement]. Москва.

Ioann [Bishop Ioann (Bereslavskii)]. 1991. Иоанн (Архиепископ Иоанн (Береславский)). Исповедь раненного сердия [Confession of a Wounded Heart]. Москва.

Khagemeister, M. 2000. Хагемейстер, М. "Миф о заговоре против России" [The Myth of the Conspiracy Against Russia], Muфbs u мифология в современной России [Myths and Mythology in Contemporary Russia]. Москва. 92-111.

Klibanov, A.I. 1969. Клибанов, А.И. Религиозное сектантство и современность [Religious Sectarianism and Contemporaneity]. Москва.

Lezov, S.V. 1996. Лёзов, С.В. История и герменевтика в изучении Нового Завета [History and Hermeneutics in the Study of the New Testament]. Москва.

Maslinskii, К.А. 2000. Маслинский, К.А. “Эсхатологические рассуждения современных крестьян" [The Eschatological Reasoning of Contemporary Peasants], Традиция в фольклоре $u$ литературе [Tradition in Folklore and Literature]. Санкт Петербург. 91-104.

Mel'nikova, Е.А. 2004. Мельникова, Е.А. "Эсхатологические ожидания рубежа XIX-XX веков: конца света не будет?" [Eschatological Expectations on the Border of the XIX-XX centuries: Will There Be No End of the World?], Антропологический форум, № 1: 250-266.

Nekliudov, S.IU. 2005. Неклюдов, С.Ю. “Структура и функции мифа" [The Structure and Function of Myth], Современная российская мифология [Contemporary Russian Mythology]. Москва. 9-26.

Novichkova, T.A. 2001. Новичкова, T.A. Эпос и миф [Epos and Myth]. Санкт -Петербург.

Ozhiganova, A.V. 2000. Ожиганова, А.В. Восточные философскорелигиозные учения и духовные практики в современной России (На примере 2. Москвы) [Oriental Philosophical-Religious Teachings and Spiritual Practices in Contemporary Russia (The Example of the City of Moscow]. Дисс... канд. ист. наук. Москва. Reutin, M.IU. 1996. Реутин, М.Ю. Народная культура Германии [Folk Culture in Germany]. Москва. 
Tarabukina, A.V. 2000. Тарабукина, А.В. Фольклор и культура прицерковного круга [Church Circle Folklore and Culture]. Дисс. ... канд. филол. наук. С.-Петербург, Глава 2.

http://www.ruthenia.ru/folktee/CYBERSTOL/books/Tarabukina/gla va 2.html. consulted 2003.

Vorob'evskii, IU. 2000. Воробьевский, Ю. Падут знамена ада [The Banners of Hell Will Fall]. Москва.

No author. 1977. Русская демократическая сатира XVII века [Russian Democratic Satire of the XVII century]. Москва. . 1991. Откровения Божией Матери в России (19841991). Дни святых благословений [The Revelations of the Mother of God in Russia. The Days of Sacred Benedictions]. Москва. . 1992. Богородичное лоно [The Mother of God's Bosom]. Кемерово.

. 1993. Поэма Величальная или Отверженные за Слово Божие [A Poem of Praise, or the Outcasts for the Sake of the God's Word]. Санкт Петербург, чч. 1-2.

. 1993. Учение Марии Деви Христос. Наука о Свете и его трансформачии. Основные формы [The Teaching of Maria Devi Khristos. A Science about the World and Its Transformation. The Fundamental Forms]. Москва.

. 1999. Электронное жало антихриста [The Electronic Sting of the Antichrist]. Москва.

. 2003. Духовное завещание стариа Иеронима. [A spiritual will of the elder, Ieronim]. This leaflet was distributed by representatives of the Orthodox Brotherhood named after the TsarExpiator Nicholas II on the territory of the Diveevo Monastery in the summer of 2003.

Translated by Svitlana P. Kukharenko 